\title{
KEANEKARAGAMAN JENIS KELELAWAR (Chiroptera) DI KAWASAN UNIVERSITAS TANJUNGPURA KOTA PONTIANAK
}

\author{
(Bats (Chiroptera) Diversity in Tanjungpura University Area, Pontianak)
}

\author{
Zunia Safitri, Hari Prayogo, Erianto \\ Fakultas Kehutanan Universitas Tanjungpura, Jalan Imam Bonjol Pontianak, 78124 \\ E-mail: zuniasafitri96@gmail.com
}

\begin{abstract}
Bat (Chiroptera) are a type of mammal that has an important ecological role for the sustainability of the forest, including helping to spread seeds, flower pollination, and control insect population. Bats have adapted well to various habitats, including urban forests. The purpose of this research is to search bats diversity data in the area of Tanjungpura University, Pontianak. Method of this research using the capture and release by using a mist net, placed purposively, by looking at the bat path. The Mist net was installed around tree canopy layers at 3 research locations, new campuses, old campuses, and the Arboretum. Based on the location of the observation, the number of species and types found in three locations is the same. There are 2 species of the family Pteropodidae including the sub-order Megachiroptera, Cynopterus brachyotis and Cynopterus minutus. Data analysis results show that no type of bat dominates from three observation locations, the dominance index is $<1$. Diversity of Bats from all three locations shows $<1$ which includes low diversity index criteria. The evenness of bats from all three observation locations has a criteria value of $>0.5$ meaning the community at all three observation locations is the lability community to the stable.
\end{abstract}

Keyword: Bats, Diversity, Urban Forest

\section{PENDAHULUAN}

Kelelawar (Chiroptera) sebagai salah satu jenis satwa yang menempati ekosistem hutan memiliki fungsi ekologis yang penting bagi kelestarian hutan. Kelelawar bermanfaat sebagai pengendali populasi serangga. Berdasarkan penelitian diperkirakan 95\% dari regenerasi hutan dilakukan oleh kelelawar jenis pemakan buah dan biji (Satyadarma, 2005; Naszami, 2019). Kelelawar merupakan salah satu komponen penting dalam kestabilan ekosistem. Salah satu peranannya membantu penyebaran biji dan penyerbukan bunga serta pengendali populasi serangga, sehingga kelelawar memiliki arti penting secara ekologis.
Kelelawar yang ada di Indonesia diperkirakan mencapai 230 Spesies atau $21 \%$ dari jenis kelelawar yang ada di dunia. Jenis tersebut diantaranya 77 Spesies dikelompokkan ke dalam Sub Ordo Megachiroptera sedangkan 153 Spesies dikelompokkan ke dalam Sub Ordo Microchiroptera (Suyanto, 2001; Simmons, 2005; Hylsandy, 2015; Trecyana, 2019). Kelelawar merupakan agen penyerbuk berbagai jenis tanaman, termasuk tanaman yang bernilai ekonomi yang tinggi seperti durian (Durio zibethinus), aren (Arenga sp.), petai (Parkia speciosa), kapuk randu (Ceiba petandra), pisang-pisangan (Musa sp.), kelapa (Cocos nucifera) (Suyanto, 2003). Serbuk sari dari 
pepohonan yang terbawa oleh kelelawar yang terbang dalam jarak yang jauh dapat meningkatkan keanekaragaman hayati.

Kelelawar masih dianggap hewan yang belum tersentuh oleh upaya konservasi. Banyak hal yang menyebabkan kelelawar masih dikesampingkan, salah satunya adalah karena masih lemahnya pengetahuan masyarakat akan arti penting kelelawar dalam rangkaian mata rantai ekologi. Meskipun peranan kelelawar pemakan serangga cukup besar, tetapi populasi kelelawar mengalami penurunan hampir di seluruh dunia. Bahkan beberapa jenis telah dinyatakan punah dan jenis lainnya mengalami proses menuju kepunahan (Falcão et al., 2003). Salah satu penyebab utama penurunan populasi kelelawar adalah degradasi habitat, yakni rusaknya habitat kelelawar di seluruh dunia akibat penebangan, konversi lahan dan kebakaran hutan baik yang terjadi oleh akibat alam maupun aktivitas manusia.

Jenis kelelawar telah beradaptasi dengan baik terhadap berbagai habitat, termasuk hutan perkotaan. Untan terletak di pertengahan kota Pontianak, akan tetapi belum ada penelitian yang dilakukan untuk mengetahui keberadaan jenis-jenis kelelawar di dalamnya, untuk itu perlu dilakukan penelitian mengenai keanekaragaman jenis kelelawar (Chiroptera) dikawasan Untan. Tujuan penelitian ini adalah untuk mencari keanekaragaman jenis kelelawar di kawasan Universitas Tanjungpura Kota Pontianak.

\section{METODELOGI PENELITIAN}

Penelitian dilaksanakan di lingkungan Fakultas Kehutanan (kampus baru, kampus lama, dan arboretum) Universitas Tanjungpura Kota Pontianak, Kalimatan Barat. Penelitian ini dilakukan selama \pm 4 Minggu, tanggal 14 Oktober sampai 5 November 2019. Alat dan bahan yang digunakan dalam penelitian diantaranya jaring kabut (mist net), tali rapia/tali plastik, sarung tangan, Head Lamp dan senter, timbangan pegas $100 \mathrm{gr}$, Califer, jarum suntik, toples, kamera, tally sheet, alkohol $70 \%$.

Penelitian menggunakan metode tangkap lepas dengan menggunakan jaring kabut (mist net). Peletakan mist net dilakukan secara purposive yaitu dengan memperhatikan jalur lalu lintas kelelawar. Mist net tersebut dipasang di sekitar lapisan tajuk pohon pada 3 lokasi penelitian diantaranya kampus baru, kampus lama dan Arboretum.

\section{Pengumpulan Data}

Waktu pemasangan mist net dilakukan sebelum jam 17.00 WIB. Untuk waktu pengecekan dilakukan pada setiap jam dilakukan sampai jam 22.00 WIB. Untuk setiap lokasi, dilakukan pengamatan dengan 1 jam sekali pengecekan ulangan. Kelelawar yang tertangkap dilakukan pengukuran morfologi dan proses identifikasi.

Menurut Payne at al (2000) dalam mengidentifikasi jenis kelelawar, bagian-bagian tubuh yang diukur meliputi Ekor (E) yaitu diukur dari ujung ekor tidak termasuk bulu atau rambut panjang yang memanjang melebihi ekor, 
Kaki Belakang (KB) yaitu dari tumit sampai ujung jari yang terpanjang tidak termasuk cakarnya, Panjang Telinga (T) yaitu diukur dari bagian luar yang terbuka sampai ujung dan Lengan Bawah (LB) yaitu dari sisi luar siku sampai sisi luar pengelangan tangan pada sayap yang melengkung.

Untuk melihat identitas masingmasing jenis, juga dilakukan pengukuran Berat (B), Panjang Kepala dan Tubuh (KT) yaitu diukur dari anus sampai di depan hidung, Panjang Jari ketiga dan kelima serta melihat Jenis Kelamin dan Umur (Dewasa atau Anak). Pengukuran morfologi, untuk memastikan identifikasi jenis juga dilakukan pengamatan terhadap susunan gigi kelelawar. Setelah dilakukan pengukuran, kelelawar yang teridentifikasi diberi tanda dan kemudian dilepaskan kembali.

\section{Analisa Data}

Data yang diperoleh dianalisis menggunakan Indeks Dominansi Simpson (C), Indeks Keanekaragaman jenis Shannon-Wiener $(\overline{\mathrm{H}})$, Indeks Kemerataan jenis Evenness (e), dan Indeks Kesamaan Jenis Sorensen (IS).

1. Indeks Dominansi (C)

Untuk mengetahui dominansi suatu jenis yang terpusat dalam komunitas digunakan rumus (Odum, 1996).

$\mathrm{C}=\sum\left[\frac{\mathrm{ni}}{\mathrm{N}}\right]^{2}$

Dimana:

$\mathrm{C}=$ Indeks Dominansi (Simpsons Indeks)

ni $=$ Jumlah individu suatu jenis

$\mathrm{N}=$ Jumlah individu seluruh jenis

Kriteria nilai indeks Dominansi adalah sebagai berikut:
$0,00<\mathrm{C} \leq 0,30$ : dominansi rendah $0,30<\mathrm{C} \leq 0,60$ : dominansi sedang $0,60<\mathrm{C}<1,00$ : dominansi tinggi

2. Indeks Keanekaragaman Jenis $(\overline{\mathrm{H}})$

Untuk mengetahui keanekaraman jenis dalam suatu komunitas digunakan Indeks Keanekaragaman Shannon (Shannon-wiener), dengan rumus (Odum, 1996) dengan rummus sebagai berikut :

$\overline{\mathrm{H}}=-\sum$ pi Ln pi

Keterangan:

$\overline{\mathrm{H}}=$ Indeks keanekaragaman jenis

pi $=$ Proporsi jumlah individu spesies-i $\left(\frac{\mathrm{ni}}{\mathrm{N}}\right)$

$\mathrm{N}=$ Total jumlah individu seluruh jenis

ni $=$ Jumlah individu spesies-i

$\mathrm{Ln}=$ Logaritma natural

Kriteria nilai indeks keanekaragaman Shannon - Wiener $(\overline{\mathrm{H}})$ adalah sebagai berikut:

$\overline{\mathrm{H}}<1 \quad$ : keanekaragaman rendah

$1 \leq \overline{\mathrm{H}} \leq 3$ : keanekaragaman sedang

$\overline{\mathrm{H}}>3 \quad$ : keanekaragaman tinggi

3. Indeks Kemerataan (Indeks

Evenness) / ( e )

Adalah untuk mengetahui tingkat kemerataan suatu jenis yang dipengaruhi oleh keragaman atau nilai kemerataan diantara jenis yang ada dalam suatu komunitas. Dengan rumus (Odum, 1996) yaitu sebagai berikut:

$\mathrm{e}=\overline{\mathrm{H}} / \mathrm{Ln} \mathrm{S}$

Keterangan:

$\overline{\mathrm{H}}=$ Indeks Shannon

$\mathrm{S}=$ Jumlah spesies

$\mathrm{e}=$ Indeks kemerataan

Kriteria nilai komunitas berdasarkan kemerataan:

$0,00<\mathrm{e} \leq 0,50 \quad:$ Komunitas Tertekan

$0,50<\mathrm{e} \leq 0,75 \quad:$ Komunitas labil

$0,75<\mathrm{e}<1,00 \quad:$ Komunitas stabil 
4. Indeks Kesamaan Jenis (Indek

Sorensen)

Untuk mengetahui besarnya indeks kesamaan dapat digunakan rumus sebagai berikut:

IS $=\frac{2 C}{A+B} \times 100 \%$

Keterangan:

IS $=$ indeks kesamaan

$\mathrm{C}=$ jumlah spesies yang sama dan terdapat pada kedua komunitas

$\mathrm{A}=$ jumlah spesies di dalam komunitas A

$\mathrm{B}=$ jumlah spesies di dalam komunitas $\mathrm{B}$

Kriteria indeks kesamaan jenis yaitu, jika IS mendekati $100 \%$ maka tingkat kesamaan tinggi.

\section{HASIL DAN PEMBAHASAN}

Berdasarkan data yang diperoleh dari ketiga lokasi pengamatan kampus lama, kampus baru dan Arboretum, jumlah total kelelawar yang ditemukan sebanyak 54 individu terdiri dari 2 spesies yaitu Cynopterus brachyotis 29 individu, Cynopterus minutus 25 individu. Kedua spesies tersebut merupakan famili Pteropodidae termasuk sub ordo Megachiroptera yang makanan utamanya adalah buah, bunga, nektar dan serbuk sari. Secara rinci dapat dilihat pada Tabel 1 berikut.

Tabel 1. Jenis Kelelawar di Kawasan Fakultas Kehutanan dan Arboretum (Types of bats in the Faculty of Forestry and Arboretum area)

\begin{tabular}{|c|c|c|c|c|c|c|c|c|}
\hline \multirow{2}{*}{ No } & \multirow{2}{*}{ Nama Latin } & \multirow{2}{*}{ Nama Lokal } & \multirow{2}{*}{ IUCN Redlist Status } & \multicolumn{3}{|c|}{ Jumlah Individu } & \multirow{2}{*}{ o } & \multirow{2}{*}{$\hat{0}$} \\
\hline & & & & $\mathrm{a}$ & $\mathrm{b}$ & $\mathrm{c}$ & & \\
\hline 1 & Cynopterus brachyotis & Codot Crawar & LC & 2 & 4 & 23 & 20 & 9 \\
\hline 2 & Cynopterus minutus & Codot Mini & LC & 11 & 1 & 13 & 11 & 14 \\
\hline \multicolumn{3}{|c|}{ Jumlah Individu } & & 13 & 5 & 36 & 31 & 23 \\
\hline
\end{tabular}

Keterangan: $\mathrm{LC}=$ Least Concern, $\mathrm{a}=$ Kampus Lama, $\mathrm{b}=$ Kampus Baru, $\mathrm{c}=$ Arboretum, $\hat{\mathrm{O}}=$ Jantan, $q=$ Betina

Hasil Pengamatan di kawasan kampus lama, kampus baru Fakultas Kehutanan dan Arboretum Universitas Tanjungpura ditemukan 2 jenis kelelawar yaitu Cynopterus brachyotis dan Cynopterus minutus. Di kampus lama dijumpai 13 individu, di kampus baru 5 individu dan Arboretum 36 individu.

Jumlah jenis yang ditemukan diseluruh lokasi adalah sama, hanya jumlah individu yang berbeda. Arboretum merupakan lokasi yang paling banyak dijumpai jumlah individunya dibandingkan lokasi yang lain. Hal ini diduga kawasan Arboretum memiliki daerah yang tertutup, bayak ditumbuhi beragam jenis pohon hutan. Kondisi sebaliknya dijumpai dikawasan Kampus Baru dan Kampus Lama Fakultas Kehutanan. Kampus Baru memiliki wilayah terbuka dikelilingi pohon yang kerapatannya kurang dibandingkan Arboretum. Demikian juga dengan Kampus Lama, sebagian sudah terbuka dan vegetasi pohon yang ada adalah pohon jenis Mahoni (Swietenia mahagoni), Kelapa Sawit (Elaeis), Akasia (Acacia), Sengon (Albizia chinensis), Matoa (Pometia pinnata), dan Trembesi (Samanea saman). 


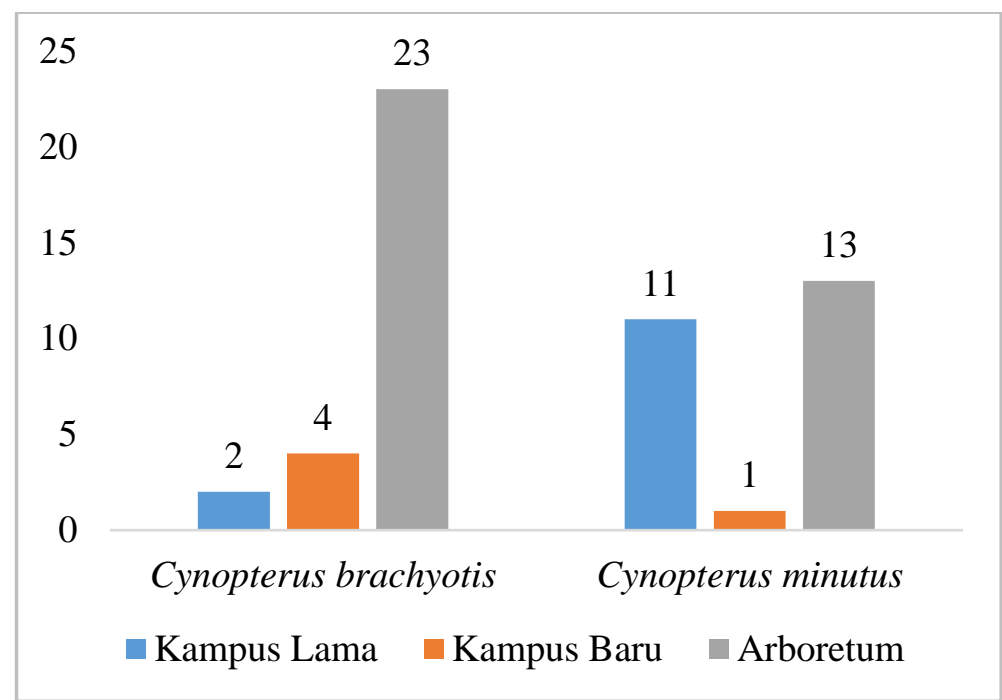

Gambar 1. Jumlah jenis kelelawar pada setiap lokasi pengamatan (Number of bats species on each observation location)

Keberadaan kelelawar disuatu habitat dipengaruhi oleh faktor lingkungan seperti kerapatan pohon, ketersediaan makanan, dan aktifitas manusia. Menurut Altringham (1996) dan Saputra et al. (2016), kelelawar sangat peka terhadap kebisingan, karena kebanyakan jenis kelelawar mempunyai alat pendengaran yang sangat sensitif sebagai adaptasi dari aktifitas hidupnya di malam hari. Kondisi lokasi arboretum memiliki kerapatan pohon lebih tinggi dan sedikit aktifitas manusia serta cendrung lebih gelap dibandingkan Kampus Baru dan Kampus Lama yang berada pada daerah perumahan. Menurut Elangovan (2001) dan Saputra et al. (2016) selain faktor lingkungan tadi,

Tabel 2. Morfometri Kelelawar di Kawasan Fakultas Kehutanan UNTAN dan Arboretum (Bats Morfometry in the Faculty of Forestry UNTAN and Arboretum area)

\begin{tabular}{cccccccc}
\multicolumn{8}{c}{ Bats Morfometry in the Faculty of Forestry UNTAN and Arboretum area $)$} \\
\hline Jenis Spesies & $\begin{array}{c}\mathrm{KT} \\
(\mathrm{mm})\end{array}$ & $\begin{array}{c}\mathrm{LB} \\
(\mathrm{mm})\end{array}$ & $\mathrm{T}(\mathrm{mm})$ & $\begin{array}{c}\mathrm{Tb} \\
(\mathrm{mm})\end{array}$ & $\begin{array}{c}\mathrm{E} \\
(\mathrm{mm})\end{array}$ & $\begin{array}{c}\mathrm{KB} \\
(\mathrm{mm})\end{array}$ & $\mathrm{B}(\mathrm{gr})$ \\
\hline Cynopterus brachyotis & $50-76$ & $38-50$ & $10-18$ & $14-28$ & $3-10$ & $8-19$ & $25-49$ \\
Cynopterus minutus & $54-68$ & $40-45$ & $12-18$ & $17-24$ & $7-9$ & $7-10$ & $20-29$ \\
\hline Keteranagan: KT = kepala dan tubuh, LB = lengan bawah, $\mathrm{T}=$ telingga, Tb = betis, E = ekor, \\
KB = kaki belakang, B = berat (gr)
\end{tabular}

Keteranagan: $\mathrm{KT}=$ kepala dan tubuh, $\mathrm{LB}=$ lengan bawah, $\mathrm{T}=$ telingga, $\mathrm{Tb}=$ betis, $\mathrm{E}=$ ekor, $\mathrm{KB}=$ kaki belakang, $\mathrm{B}=$ berat $(\mathrm{gr})$ cahaya dari bulan purnama sangat berpengaruh terhadap aktivitas kelelawar, kegiatan mencari makan kelelawar berbanding terbalik dengan cahaya bulan, dimana kegiatan mencari makan sangat minim ketika bulan purnama.

Spesies Cynopterus brachyotis yang ditemukan dikawasan Fakultas Kehutanan UNTAN dan Arboretum memiliki ukuran panjang tubuh berkisar antara 50-56 $\mathrm{mm}$ dengan berat 25-49 gram, sedangkan Cynopterus minutus memiliki ukuran panjang tubuh berkisar antara 54-68 mm dengan berat 20-29 gram. Secara rinci dapat dilihat pada Tabel 2 berikut. 


\section{Cynopterus brachyotis (Codot Krawar)}

Merupakan kelelawar berukuran sedang dengan panjang lengan bawah 44,9-66 mm. Jenis ini tersebar di Nepal, India Thailand, Indocina, Kepulauan Andaman dan Nicobar, Malaysia,
Sumatera, Kalimantan, Jawa dan Bali (Corbet dan Hill, 1992; Suyanto, 2001). Status konservasi menurut IUCN (2019) kelelawar codot crawar berstatus Least Concern (LC).

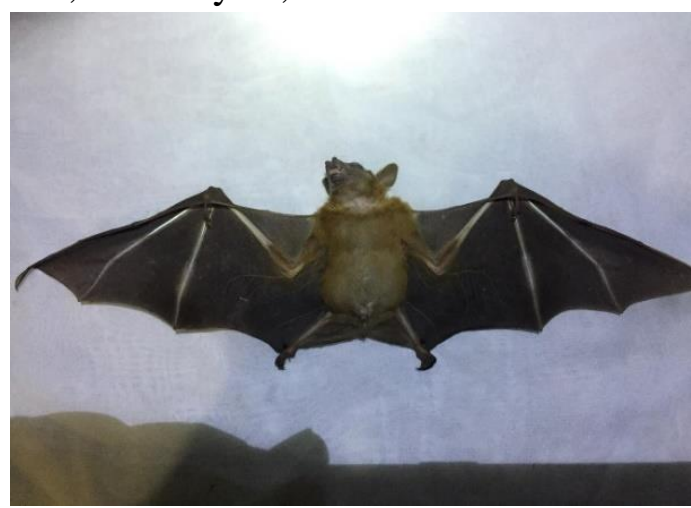

Gambar 2. Codot Crawar (Cynopterus brachyotis)

Tersebar di seluruh Indonesia, kecuali Papua Barat. Ciri-ciri panjang lengan bawah 55-71 $\mathrm{mm}$, tepi telinga putih, panjang ekor 6-11 mm, panjang telinga 9-16 mm, panjang betis $18-26$ $\mathrm{mm}$, panjang kaki belakang 9-16 $\mathrm{mm}$, berat badan 30-50 gr, memiliki dua pasang gigi seri bawah, kelelawar ini umumnya berwarna coklat sampai cokelat kekuningan dengan kerah jingga tua lebih terang pada jantan dewasa, kekuningan pada betina. Anakan lebih abu-abu dengan kerah tidak jelas. Tulang-tulang pada telinga dan sayap biasanya bertepi putih (Payne et al., 2000).

\section{Cynopterus minutus (Codot Mini)}

Kelelawar pemakan buah ini ditemukan hanya di Indonesia (Sumatra, Kalimantan Jawa dan Sulawesi). Dalam bahasa Inggris, codot ini dikenal sebagai Minute Fruit Bat. Merupakan kelelawar berukuran kecil dari Marga Cynopterus, panjang lengan bawah 53-60 mm (Corbet dan Hill, 1992; Suyanto, 2001).

Status konservasi menurut IUCN (2019) kelelawar codot mini berstatus Least Concern (LC). 


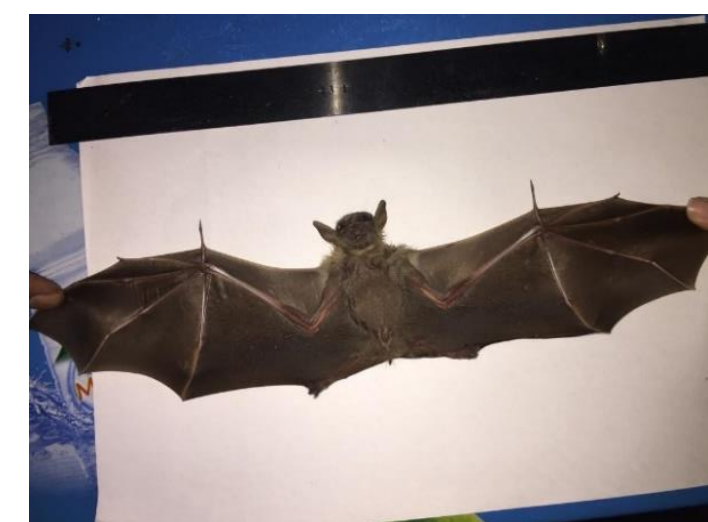

Gambar 3. Codot Mini (Cynopterus minutus)

Ciri-ciri panjang lengan bawah 52$61 \mathrm{~mm}$, tepi telinga berwarna putih, panjang telinga 13-23 mm, panjang betis 9-23 mm, panjang ekor 7-12 $\mathrm{mm}$, berat badan 40 gr, kelelawar ini umumnya mempunyai selaput kulit antar paha yang berlekatan dengan ekor atau tulang ekor. Perlekatan ekor ini dapat terjadi seluruhnya atau sebagian kecil. Pada kelelawar Codot Mini selaput kulit antar pahanya tidak berkembang, sehingga memiliki ekor yang pendek. Memiliki mata yang besar, telinganya tidak memiliki tragus atau antitargus. Gigi geraham tumpul, gigi serinya tidak terbelah di bandingkan ujungnya. Kelelawar codot mini ini mempunyai moncong yang pendek, hidungnya agak besar menyerupai tabung (Suyanto, 2001).
Indeks Dominasi (C), Indeks Keanekaragaman Jenis $(\overline{\mathbf{H}})$ dan Indeks Kemerataan jenis (e)

Hasil Analisis data menunjukan bahwa tidak terdapat jenis kelelawar yang mendominasi dari ketiga lokasi pengamatan, karena ketiga lokasi tersebut memiliki kriteria indeks dominasi < 1 . Keanekaragaman jenis kelelawar dari ketiga lokasi menunjukan $<1$ dimana termasuk kriteria indeks keanekaragaman rendah.

Kemerataan jenis kelelawar dari ketiga lokasi pengamatan memiliki nilai kriteria > 0,5 artinya komunitas pada ketiga lokasi pengamatan merupakan komunitas labil hingga stabil. Secara rinci nilai indeks dapat dilihat pada Gambar 4 berikut. 


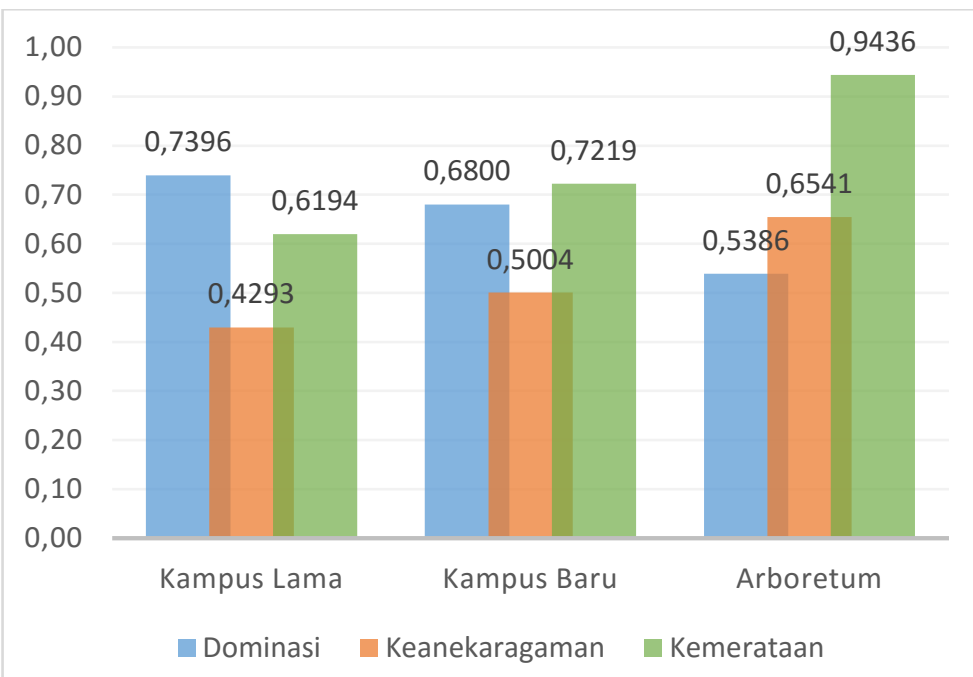

Gambar 4. Nilai Indeks Dominasi, Indeks Keanekaragaman, dan Indeks Kemerataan pada lokasi pengamatan (Simpson Domination Index, Shannon Diversity Index and evenness index at the observation location)

Nilai Indeks Dominasi jenis kelelawar terendah dari ketiga lokasi pengamatan berada di lokasi Arboretum dengan nilai indeks 0,5386 , sedangkan nilai indeks tertinggi berada di lokasi kampus lama Fakultas Kehutanan dengan nilai 0,7396. Nilai Indeks Keanekaragaman jenis kelelawar terendah dari ketiga lokasi pengamatan berada di lokasi kampus lama dengan nilai 0,4293, sedangkan nilai indeks tertinggi berada di lokasi Arboretum dengan nilai 0,6541. Nilai Indeks Kemerataan jenis kelelawar terendah dari ketiga lokasi pengamatan berada di lokasi kampus lama dengan nilai 0,6194, sedangkan nilai indeks tertinggi berada di lokasi Arboretum dengan nilai 0,9436. Secara keseluruhan dapat dilihat pada Tabel 3 berikut.

Tabel 3. Indeks Dominasi (C), Indeks Keanekaragaman Jenis $(\overline{\mathrm{H}})$ dan Indeks Kemerataan jenis (e) Kelelawar (Simpson domination index $(C)$, Shannon Diversity index $(\bar{H})$ and evenness index (e))

\begin{tabular}{lccccccccc}
\hline \multirow{2}{*}{ Spesies } & \multicolumn{4}{c}{$\mathrm{C}$} & \multicolumn{3}{c}{$\overline{\mathrm{H}}$} & \multicolumn{3}{c}{$\mathrm{e}$} \\
\cline { 2 - 10 } & $\mathrm{a}$ & $\mathrm{b}$ & $\mathrm{c}$ & $\mathrm{a}$ & $\mathrm{b}$ & $\mathrm{c}$ & $\mathrm{a}$ & $\mathrm{b}$ & $\mathrm{c}$ \\
\hline C. brachyotis & 0,0237 & 0,6400 & 0,4082 & 0,2880 & 0,1785 & 0,2862 & 0,4155 & 0,2575 & 0,4130 \\
C. minutus & 0,7160 & 0,0400 & 0,1304 & 0,1414 & 0,3219 & 0,3678 & 0,2039 & 0,4644 & 0,5306 \\
\hline \multicolumn{1}{c}{ Jumlah } & 0,7396 & 0,6800 & 0,5386 & 0,4293 & 0,5004 & 0,6541 & 0,6194 & 0,7219 & 0,9436 \\
\hline
\end{tabular}

Keterangan: Indeks Dominasi $(\mathrm{C})$, Indeks Keanekaragaman $(\overline{\mathrm{H}})$, Indeks Kemerataan $(\mathrm{e})$ $\mathrm{a}=$ Kampus Lama, $\mathrm{b}=$ Kampus Baru, $\mathrm{c}=$ Arboretum

\section{Indeks Dominasi (C)}

Jenis spesies kelelawar yang ditemukan pada lokasi kampus lama tidak berbeda dari Arboretum dan kampus baru yaitu Cynopterus brachyotis (codot crawar) dan Cynopterus minutus (codot mini) dengan jumlah total sebanyak 13 individu. Hasil analisis data dari kedua spesies tersebut menunjukan nilai Indeks Dominasi 
codot crawar (C. brachyotis) sebesar 0,0237, sedangkan codot mini ( $C$. minutus) memiliki nilai Indeks Dominasi lebih besar sebesar 0,7160 , jumlah total Indeks Dominasi dari kedua spesies tersebut sebesar 0,7396. Dari nilai Indeks Dominasi tersebut dapat dijelaskan bahwa tidak terdapat spesies yang mendominasi pada lokai kampus lama karena nilai indeks berada pada kriteria $0,7396<1$ dengan kriteria dominasi tinggi. Berbeda dari kedua lokasi pada kampus baru dan Arboretum, pada kampus lama $C$. minutus lebih dominan atau paling banyak dijumpai.

Di lokasi kampus baru ditemukan jumlah spesies yang sama sebanyak 2 jenis spesies yaitu Cynopterus brachyotis (codot crawar) dan Cynopterus minutus (codot mini) dengan jumlah total lebih sedikit dibandingkan dengan Arboretum sebanyak 5 individu. Jumlah total Indeks Dominasi dari kedua spesies tersebut sebesar 0,6800. Hasil analisis data dari kedua spesies tersebut menunjukan nilai Indeks Dominasi codot crawar (C. brachyotis) lebih besar yaitu 0,6400 , sedangkan codot mini $(C$. minutus) memiliki nilai Indeks Dominasi lebih kecil sebesar 0,0400. Dari nilai Indeks Dominasi tersebut dapat dijelaskan bahwa tidak terdapat spesies yang mendominasi pada lokasi kampus baru karena nilai indeks berada pada kriteria $0,6800<1$ dengan kriteria dominasi sedang.

Terdapat 2 jenis spesies yang ditemukan pada lokasi Arboretum yaitu Cynopterus brachyotis (codot crawar) dan Cynopterus minutus (codot mini) dengan jumlah total sebanyak 36 individu. Hasil analisis data dari kedua spesies tersebut menunjukan nilai Indeks Dominasi codot crawar (C. brachyotis) sebesar 0,4082, sedangkan codot mini (C. minutus) memiliki nilai Indeks Dominasi lebih kecil sebesar 0,1304, jumlah total Indeks Dominasi dari kedua spesies tersebut sebesar 0,5386. Dari nilai Indeks Dominasi tersebut dapat dijelaskan bahwa tidak terdapat spesies yang mendominasi pada lokai Arboretum karena nilai indeks berada pada kriteria < 1 dengan kriteria dominasi sedang. C. brachyotis lebih dominan atau merupakan jenis yang paling banyak jumlah individunya diseluruh lokasi.

\section{Indeks Keanekaragaman Jenis $(\overline{\mathbf{H}})$}

Dibandingkan dengan lokasi Arboretum dan kampus baru nilai Indeks Keanekaragaman kelelawar di kampus lama lebih kecil yaitu adalah sebesar 0,4293, dapat dijelaskan bahwa keanekaragaman jenis berada pada kriteria rendah $0,4293<1$. Hal ini diduga karena aktifitas manusia, kampus lama yang berada pada daerah perumahan dan dekat dengan jalan besar. Kebisingan dari mesin kendaraan berpengaruh terhadap keberadaan kelelawar. Hal ini sesuai dengan pernyataan Odum (1971) dan Darmawan (2005) bahwa keanekaragaman identik dengan kestabilan suatu ekosistem, yaitu jika keanekaragaman suatu ekosistem relatif tinggi maka kondisi ekosistem tersebut cenderung stabil dan keanekaragaman jenis cenderung rendah pada ekosistem yang terganggu. 
Jumlah individu yang dijumpai di kampus baru lebih sedikit serta keanekaragaman jenis kelelawar di lokasi kampus baru rendah dibandingkan Arboterum. Hal ini diduga karena kampus baru memiliki pohon yang kerapatannya kurang serta wilayah yang terbuka. Nilai Indeks Keanekaragaman kelelawar di kampus baru adalah sebesar 0,5004. Dari nilai tersebut dapat dijelaskan bahwa keanekaragaman jenis berada pada kriteria rendah 0,5004 $<1$.

Keanekaragaman jenis kelelawar di lokasi Arboretum lebih tinggi dibandingkan kampus baru dan kampus lama. Hal ini diduga disebabkan dengan tingginya keanekaragaman jenis tumbuhan yang terdapat di Arboretum. Selain tanaman kehutanan terdapat pohon pisang (Musa paradisiaca), mangga (Mangifera indica), jambu (Syzygium aqueum) di sekitar Arboretum di mana banyak kelelawar pemakan buah mencari makan, dan bersarang. Nilai Indeks Keanekaragaman kelelawar di Arboretum adalah sebesar 0,6541, dapat dijelaskan bahwa keanekaragaman jenis berada pada kriteria rendah $0,6541<1$.

\section{Indeks Kemerataan jenis (e)}

Indeks Kemerataan pada lokasi kampus lama memiliki nilai paling rendah dibandingkan dua lokasi lainnya sebesar 0,6194. Dari nilai Indeks Tabel 6. Indeks Kesamaan Jenis (IS) (Sorensen similarity index, IS)

\begin{tabular}{llcc}
\multicolumn{2}{l}{ Tabel 6. Indeks Kesamaan Jenis (IS) (Sorensen similarity index, IS) } \\
\hline \multicolumn{1}{c}{ Lokasi } & \multicolumn{1}{c}{ Jenis Spesies } & Kesamaan \\
\hline Arboretum & $\begin{array}{l}\text { Cynopterus brachyotis } \\
\text { Cynopterus minutus }\end{array}$ & $\mathrm{Ab}-\mathrm{Kb}$ & $100 \%$ \\
Kampus Lama & $\begin{array}{l}\text { Cynopterus brachyotis } \\
\text { Cynopterus minutus }\end{array}$ & $\mathrm{Ab}-\mathrm{Kl}$ & $100 \%$ \\
Kampus Baru & $\begin{array}{l}\text { Cynopterus brachyotis } \\
\text { Cynopterus minutus }\end{array}$ & $\mathrm{Kb}-\mathrm{Kl}$ & $100 \%$ \\
\hline
\end{tabular}

Keterangan: $\mathrm{Ab}=$ Arboretum, $\mathrm{Kb}=$ Kampus baru, $\mathrm{Kl}=$ Kampus lama
Kemerataan tersebut dapat dijelaskan bahwa komunitas berada pada kriteria labil $<0,75$.

Nilai Indeks Kemerataan Codot crawar (C. brachyotis) sebesar 0,2575, dan nilai Indeks Kemerataan codot mini (C. minutus) sebesar 0,4644, jumlah total Indeks Kemerataan dari kedua spesies tersebut sebesar 0,7219. Dari nilai Indeks Kemerataan tersebut dapat dijelaskan bahwa komunitas berada pada kriteria labil $<0,75$.

Kemerataan kelelawar pada lokasi arboretum Arboretum lebih tinggi dibandingkan lokasi kampus baru dan kampus lama. Nilai indeks kemerataan codot crawar ( $C$. brachyotis) sebesar 0,4130, dan codot mini (C. minutus) sebesar 0,5306, jumlah total Indeks kemerataan dari kedua spesies tersebut yaitu sebesar 0,9436. Dari nilai Indeks Kemerataan tersebut dapat dijelaskan bahwa komunitas berada pada kriteria stabil > 0,75 atau mendekati 1 .

\section{Indeks Kesamaan Jenis (IS)}

Indeks Kesamaan Jenis dari ketiga lokasi pengamatan di lokasi kampus baru, kampus lama dan arboretum sebesar 100\%, karena jumlah jenis spesies yang ditemukan pada ketiga lokasi tersebut sama. secara rinci dapat dilihat pada Tabel 6 berikut. 
Jumlah jenis yang dijumpai di ketiga lokasi penelitian adalah sama, hanya ada 2 jenis yaitu $C$. brachyotis dan $C$. minutus. Kedua jenis tersebut memiliki sebaran di habitat yang cukup beragam dan termasuk ke dalam jenis yang dapat beradaptasi terhadap perubahan habitat. Keanekaragaman hayati rendah, hal ini terjadi karena hanya dijumpai 2 jenis di seluruh lokasi. Kondisi kampus lama terletak ditepi jalan yang ramai dan di dominasi tanaman Kelapa Sawit (Elaeis guineensis) dan Mahoni (Swietenia mahagoni), kampus baru di dominasi tanaman Mahang (Macaranga sp.), serta kondisi Arboretum merupakan kawasan di dominasi tanaman kehutanan, pada penelitian ini hanya dijumpai 2 jenis kelelawar dike tiga lokasi tersebut.

\section{KESIMPULAN}

Berdasarkan hasil penelitian diidentifikasi terdapat 2 (dua) jenis kelelawar yang dijumpai di sekitar kampus lama, kampus baru, dan Arboretum Fakultas Kehutanan Universitas Tanjungpura yaitu jenis Cynopterus brachyotis dan Cynopterus minutus. Arboretum merupakan lokasi paling banyak individu yang dijumpai. Tidak terdapat jenis kelelawar yang mendominasi dari ketiga lokasi pengamatan, kriteria keanekaragaman rendah dan kemerataan jenis merupakan komunitas labil hingga stabil. Jumlah jenis yang dijumpai di ketiga lokasi penelitian adalah sama, hanya ada 2 jenis yaitu $C$. brachyotis dan $C$. minutus. Kedua jenis tersebut memiliki sebaran yang cukup luas dan dapat bertahan hidup di habitat yang merupakan pemukiman masyarakat.

\section{SARAN}

Penghujan, penelitian lebih lanjut disarankan untuk dilakukan pada musim kemarau sehingga pengamatan lebih komprehensif dan diharapkan akan dijumpai jenis kelelawar yang berbeda.

\section{DAFTAR PUSTAKA}

Altringham JD. 1996. Bats Biology and Behaviour. Oxford University Press, New York.

Csorba G, Bumrungsri S, Bates $\mathrm{P}$, Gumal M, Kingston T, Molur S \& Srinivasulu C. 2019. Cynopterus brachyotis. The IUCN Red List of Threatened Species 2019: https://www.iucnredlist.org/specie s/6103/22113381. Diakses Januari 2020

Elangovan V, Marimuthu G, Kunz T. 2001. Nectar Feeding Behaviour in The Short-Nosed Fruit Bat Cynopterus Sphinx (Chiroptera: Pteropodidae). Acta Chiropterologica 2:1-5.

Falcão FDC, Rebêlo VF, Talamoni SA. 2003. Structure of Bat Assemblages (Mammalia, Chiroptera) in Serra do Caraça, South-East Brazil. Revista Brasileira de Zoologia 20(2): 347350.

Naszami, Anwari SM, Rifanjani S. 2019. Keanekaragaman Jenis Kelelawar Di Kawasan Camp Lubuk Baji Taman Nasional Gunung Palung. Jurnal Hutan Lestari 7 (1): 56-61.

Payne J, Francis CM, Phillipps K, Kartikasari SN. 2000. Panduan Lapangan Mamalia di Kalimantan, Sabah, Sarawak \& Brunei Darussalam. The Sabah 
Society, Wildlife Conservation Society dan World Wildlife Fund Malaysia.

Ruedas L \& Suyanto A. 2019. Cynopterus minutus. The IUCN Red List of Threatened Species 2019:

https://www.iucnredlist.org/specie s/136423/21985433. Diakses Januari 2020

Saputra Y, Sukandar P, Suryanda A. 2016. Studi Keanekaragaman Jenis Kelelawar (Chiroptera) Pada Beberapa Tipe Ekosistem Di Camp Leakey Kawasan Taman Nasional Tanjung Puting (TNTP), Kalimantan Tengah. BIOMA 12 (1): 53-58.

Satyadharma A. 2005. Hidup Bersama

Kelelawar. Jurnal Tropika Indonesia. (9): 3-4.
Simmons NB. 2005. Order Chiroptera. In: Wilson DE, Reeder (eds) Mammals Species of The World: A Taxonomic and Geographic Reference. John Hopkins University Press, Baltimore.

Suyanto A. 2001. Kelelawar di Indonesia. Bogor: Puslitbang Biologi LIPI.

Suyanto A. 2003. Kelelawar Pemakan Buah dari Taman Nasional Gunung Halimun. Zoo Indonesia, 5 (2): 31-40.

Trecyana L, Dewantara I, Erianto. 2019. Keanekaragaman Jenis Kelelawar (Chiroptera) Di Hutan Kota Teluk Akar Bergantung Kabupaten Ketapang. Jurnal Hutan Lestari Vol. 7 (1): 198-203. 